\title{
Analysis of bovine cysticercosis in the state of Goiás, Brazil and economical losses for beef farms
}

\author{
FERNANDA MARTINS DE AQUINO ${ }^{1}$, VANDO EDÉSIO SOARES ${ }^{2}$, GABRIEL \\ AUGUSTO MARQUES ROSSI ${ }^{3}$, LUIZ ANTÔNIO CARDOSO DANIN ${ }^{4}$, JOÃO \\ EDUARDO NICARETTA ${ }^{1}$, THIAGO DE SOUZA AZEREDO BASTOS ${ }^{1}$, LEONARDO \\ BUENO CRUVINEL ${ }^{1}$, GUSTAVO FELIPPELLI ${ }^{3}$, BRENO CAYEIRO CRUZ ${ }^{3}$, WILLIAN \\ GIQUELIM MACIEL ${ }^{3}$, LUCAS VINICIUS COSTA GOMES ${ }^{3}$ and WELBER DANIEL \\ ZANETTI LOPES ${ }^{5} *$ \\ ${ }^{1}$ Escola de Veterinária e Zootecnia, Universidade Federal de Goiás (EVZ/UFG), Campus Samambaia, CEP 74·690-900, \\ Goiânia, GO, Brasil \\ ${ }^{2}$ Universidade Brasil - Campus de Descalvado, CEP 13690-970, São Paulo, SP, Brasil \\ ${ }^{3}$ Faculdade de Ciências Agrárias e Veterinárias (FCAV), Universidade Estadual Paulista (UNESP), CEP 14884-900, \\ Faboticabal, SP, Brasil \\ ${ }^{4}$ Ministério da Agricultura Pecuária e Abastecimento (MAPA/SFA-GO), CEP 74003-010, Goiânia, GO, Brasil \\ ${ }^{5}$ Instituto de Patologia Tropical e Saúde Pública, Universidade Federal de Goiás (IPTSP/UFG), CEP 74605-050, \\ Goiânia, GO, Brasil
}

(Received 19 April 2017; revised 8 Fuly 2017; accepted 10 fuly 2017)

\section{SUMMARY}

This study aimed to assess the prevalence and spatial distribution of bovine cysticercosis in the state of Goiás, Brazil; to verify its association with epidemiological variables, and to establish the economical losses for beef farms. A set of 23255979 bovines from 246 municipalities were slaughtered from 2007 through 2014. The prevalence of bovine cysticercosis was $0 \cdot 53 \%$ [95\% confidence interval (95\% CI) 0.5295-0.5354]. The Central mesoregion showed a higher risk [odds ratio $(\mathrm{OR})=4 \cdot 44 ; 95 \%$ CI 4.2936-4.5895] for detecting infected animals with cysticerci compared with those raised at North and Northeast mesoregion $(\mathrm{OR}=1.02$ and $\mathrm{OR}=1.02)$. The microregion of Goiânia had a higher risk for bovine cysticercosis occurrence $(\mathrm{OR}=11 \cdot 05$, 95\% CI 10.6933-11.4099) compared with the microregion of São Miguel do Araguaia $(\mathrm{OR}=1)$. None of the epidemiological variables evaluated in this study was significantly associated $(P>0 \cdot 05)$ with bovine cysticercosis prevalence.

In conclusion, the prevalence of bovine cysticercosis in the state of Goiás, Brazil, was $0 \cdot 53 \%$ and some mesoregions and microregions presented a higher risk for its occurrence. The economical losses due to its occurrence during the period ranged from US\$9 $260728 \cdot 57$ to $11313816 \cdot 67$. These results highlighted the needs of adopting prophylactic measures and the development of political strategies in specific regions in order to control this zoonose and reduce the economical losses for beef production chain and the costs for public health.

Key words: epidemiology, geographic information system (GIS), spatial distribution, taeniasis-cysticercosis, zoonose.

\section{INTRODUCTION}

The Taenia saginata-cysticercosis is a disease caused by one parasite that requires two hosts during its life cycle. Human beings and bovines are considered as definitive and intermediate hosts, respectively. The cattle infections occur through the ingestion of T. saginata eggs (Lopes et al. 2014).

Bovine cysticercosis is the most common disease detected during inspection of cattle's carcasses and viscera in Brazil. The prevalence values are probably underestimated because the ongoing model of sanitary inspection has a low sensitivity due to the possible presence of cysticerci in muscles and viscera, which are not routinely inspected (Lopes et al. 2011.). However, meat inspection is required in

* Corresponding author: Instituto de Patologia Tropical e Saúde Pública, Universidade Federal de Goiás (IPTSP/UFG), CEP 74605-050, Goiânia, GO, Brasil. E-mail:wdzlopes@hotmail.com order to avoid its transmission to human beings and to provide information for health institutions regarding its occurrence in farms, municipalities and regions (Onyango-Abuje et al. 1996; Minozzo et al. 2002; Fukuda, 2003; Giovannini et al. 2014).

The states of Goiás, Mato Grosso, Mato Grosso do Sul, São Paulo, Minas Gerais, Pará and Rondônia raised $72 \%$ of bovines, which were slaughtered in Brazil, contributing to keep the country in the second position in the raking of world's beef producers and allowing export of beef to 143 countries. Additional values of 1.9 and $4.4 \%$ in beef production and export in Brazil is estimated from 2014 through 2024 (BRASIL, 2014).

There is a need of developing and adopting sanitary control programmes during cattle raising in Brazil in order to reduce the risk of $T$. saginatacysticercosis transmission worldwide considering the raising tendency of Brazilian beef export. According to Brazil (1952), carcasses considered as 
infected need to be heat-treated using freezing in order to inactivate the parasite.

To neglect this disease causes trade barriers and estoppels to Brazilian beef in global market and also economical losses to beef production chain (Rossi et al. 2015).

The prevalence of bovine cysticercosis in Brazil is $1.05 \%$ and differences on its value is reported among several states. In Goiás, the reported prevalence is 0.78\% (Dutra et al. 2012).

In order to contribute to the knowledge about bovine cysticercosis epidemiology in this state, this study aimed to assess the prevalence and spatial distribution of bovine cysticercosis in the state of Goiás, Brazil; to verify its association with epidemiological variables, and to establish the economical losses for beef farms.

\section{MATERIALS AND METHODS}

A retrospective study regarding bovine cysticercosis occurrence was performed through accessing the database from Brazilian Ministry of Agriculture, Livestock and Food Supply (MAPA http://www. agricultura.gov.br/assuntos/inspecao/produtos-animal/ sif/servico-de-inspecao-federal-sif), which contains data provided by the Federal Inspection Service (SIF). A set of 23255979 bovines from 246 municipalities in the state of Goiás, Brazil, including both genders and age ranging from 18 to 60 months were inspected through the years 2007-2014.

The animals were slaughtered according to the standardized technology, and the carcasses and viscera were inspected according to Brazilian legislation (Brazil, 1952). SIF adopts post-mortem inspection for bovine cysticercosis through incisions in muscles (masseteres, pterygoids, tongue and heart), palpation and visual examination of head, viscera and carcasses external surfaces according to the Regulation of Sanitary and Industrial Inspection of Animal's Products Origin (RIISPOA) (Brazil,
1952). The cysticerci were classified as viable and unviable according to their characteristics (translucent or opaque, respectively).

The obtained data were grouped per year (from 2007 to 2014), mesoregions and microregions from this state (Figures 1AB). This study included five mesoregions (Central, East, North, Northeast and South) and 18 microregions (Anápolis, Anicuns, Aragarças, Catalão, Ceres, Chapada dos Veadeiros, Entorno do Distrito Federal, Goiânia, Iporá, Meia Ponte, Pires do Rio, Porangatu, Quirinópolis, Rio Vermelho, São Miguel do Araguaia, Sudoeste de Goiás, Vale do Rio dos Bois and Vão do Paranã) according to the classification from Brazilian Institute of Geography and Statistics (IBGE, 2016, http://cidades.ibge.gov.br/xtras/uf.php?lang=\&coduf= $52 \&$ search=goias).

The prevalence and the $95 \%$ confidence interval (95\% CI) were calculated through the Wilson's method (Thrusfield, 2010). The relation among bovine cysticercosis in municipalities, mesoregions and microregions was calculated using that one with the lower prevalence [considered as odds ratio $(\mathrm{OR})=1]$ and the others were compared with it. $Z$ test was used to evaluate significance $(P<0.05)$ ('Thrusfield, 2010).

Data regarding the human population density (inhab per $\mathrm{km}^{2}$ ), Human Development Index (IDH), poverty incidence index, cattle population size, area of temporary tillage (ha), grassland area (ha), sugarcane area (ha), farmer condition (seated without definitive title) and numbers of houses without sanitary room were obtained from IBGE website (http://cidades.ibge.gov.br/xtras/uf.php? lang $=\&$ coduf $=52 \&$ search $=$ goias $)$. The classification of tourism practices was also obtained through from the state of Goiás Government website (www.goiasturismo.go.gov.br).

The association among bovine cysticercosis prevalence in municipalities (dichotomized using the median value - zero and one for the values below (a)

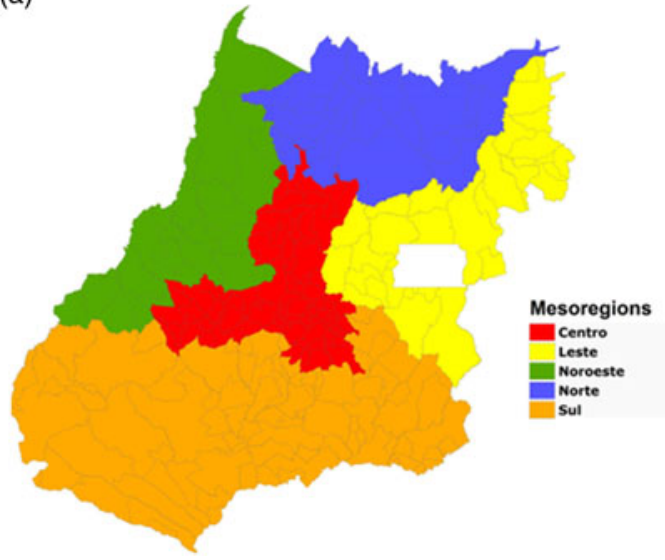

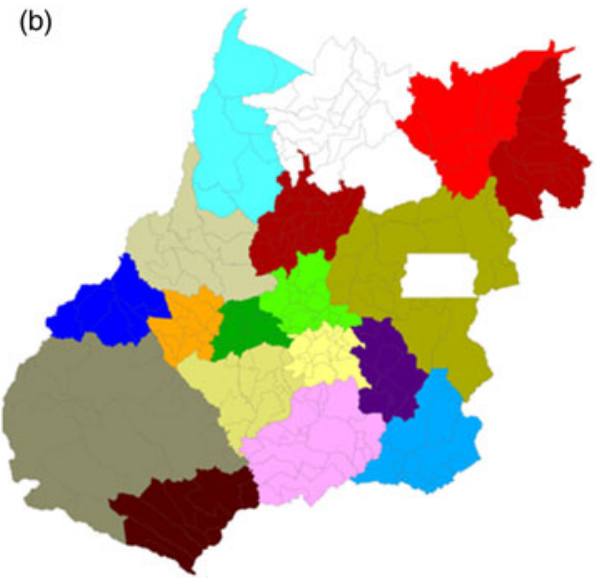

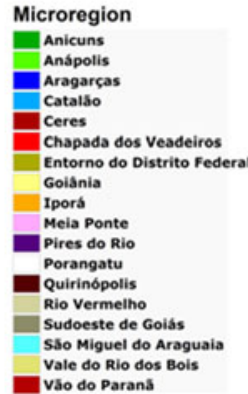

Fig. 1. Mesoregions (a) and microregions (b) in the state of Goiás, Brazil. 
and above, respectively) with epidemiological factors, such as human population density (inhab/ $\mathrm{km}^{2}$ ), forage area (ha), sugar cane area (ha), producer's condition (settled with or without permanent title), houses without sanitary room and touristic practices.

A simple binary logistic regression analysis was applied to all variables mentioned above, and those with $P \leq 0 \cdot 20$ were selected.

Then, a multivariate binary logistic regression analysis was performed using the significant variables in the univariate analysis $(P \leq 0 \cdot 20)$. The strength of the association between dependent and independent variables was estimated by OR, which was obtained from logistic regression estimations $(P \leq 0 \cdot 05)$.

The economic losses were estimated based on bovine cysticercosis prevalence and the penalties applied to farms suppliers of infected cattle using the scheme adopted by slaughterhouses in this state. Carcasses with intense cysticercosis infections, i.e. more than one cysticercus in an area of about 22 $\mathrm{cm}^{2}$, must be rendered and consequently the producer is not paid. Mild-to-moderate infections require freezing or canning and the producer receives 30$50 \%$ of the value, for unviable or viable cysticercosis, respectively. The carcasses' weight were considered as $225 \mathrm{~kg}$ and their value was gathered from Center of Advanced Studies and Applied Economy ESALQ/USP (CEPEA) from December from 2017 to 2014. The dollar conversion rate used was | US $\$ 1 \cdot 00=\mathrm{R} \$ 3 \cdot 15$ (reais).

Statistical analyses were performed using software Epi Info, v. 7.1.5.2 (https://www.cdc.gov/ epiinfo/index.html). Maps were created using the Terraview ${ }^{\circledR}$ software (http://www.dpi.inpe.br/ terraview/index.php_) through quantile method (divided in four categories).

(a)

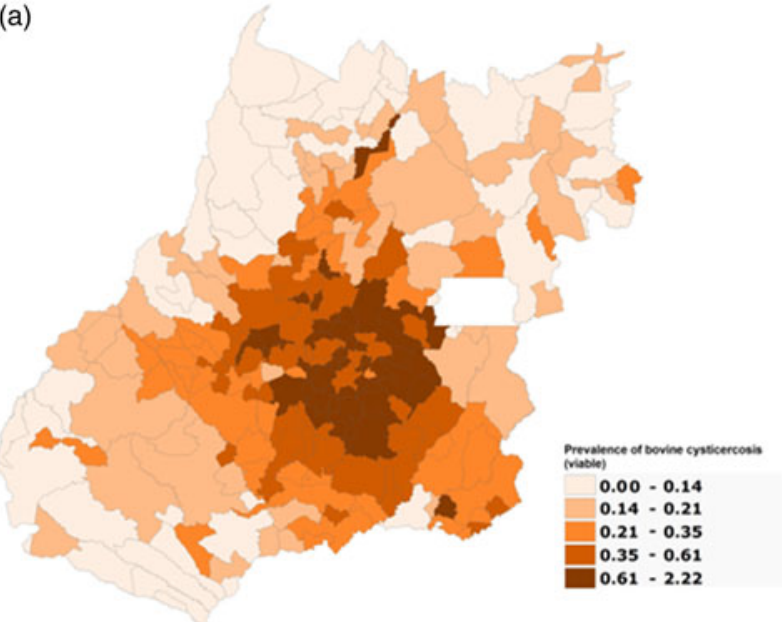

RESULTS

A set of 123728 bovines were considered as infected with cysticerci from the 23255979 animals slaughtered (prevalence $=0.53 ; 95 \%$ CI $0 \cdot 5295-0 \cdot 5354$ ) through the years 2007-2014 in the state of Goiás, Brazil. Among the cysticerci detected, 52351 and 71377 were considered as viable and unviable, respectively. The areas considered with highbovine cysticercosis prevalence (viable and unviable) are located in the centre of the state of Goiás (Figs. $2 \mathrm{~A}$ and $\mathrm{B})$.

The Central mesoregion was considered as the one with the highest prevalence $(P=1.01 \%$; 95\% CI 4.2936-4.5895) during this period, while South $(0 \cdot 62 \%)$, North $(0 \cdot 23 \%)$ and Northeast $(0 \cdot 23 \%)$ regions showed low-prevalence values (Figs. 2A and $\mathrm{B}$ and Table 1).

A significant statistical difference $(P \leq 0.05$ on risk for bovine cysticercosis occurrence through the years was observed at $2008(\mathrm{OR}=1 \cdot 31$; CI 1.2650 $1 \cdot 3664), 2013(\mathrm{OR}=1 \cdot 07$; CI 1·0271-1·1170) and $2014(\mathrm{OR}=1 \cdot 34$; CI 1·2884-1·3958). However, the areas considered as with higher prevalence were not modified (Fig. 3 and Table 2).

None of the variables, such as human population density (inhab per $\mathrm{km}^{2}$ ), IDH, poverty incidence index, cattle population size, area of temporary tillage (ha), grassland area (ha), sugarcane area (ha), farmer condition (seated without definitive title), numbers of residences without sanitary room and municipalities categorized as touristic, were significantly associated $(P>0 \cdot 05)$ with bovine cysticercosis prevalence in municipalities.

This study performed a simulation of the economic losses during the study period using the prevalence value in this state $(0.53 \%)$, carcasses weight $(225 \mathrm{~kg})$ and carcasses prices (Table 3$)$. The economical losses for beef farmers located in the

(b)

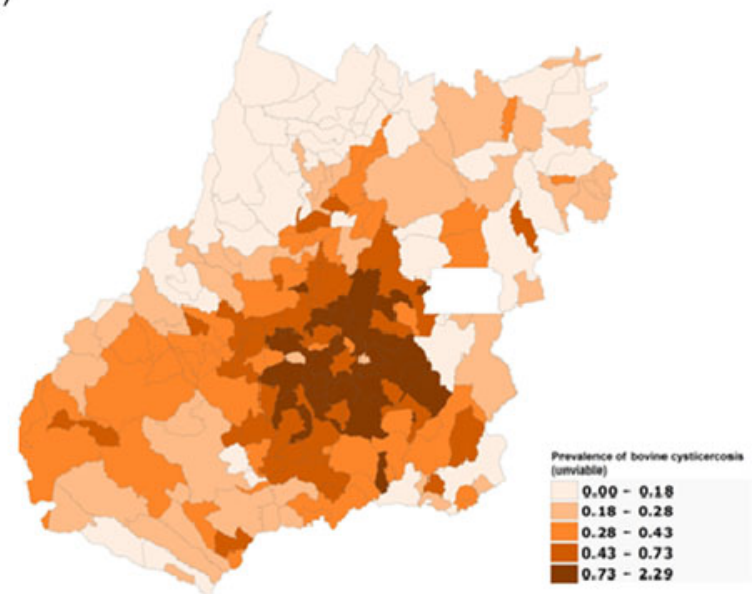

Fig. 2. Spatial distribution of bovine cysticercosis prevalence in the state of Goiás, Brazil, through the years $2007-2014$. (a) viable cysticerci; (b) unviable cysticerci. 
Table 1. Analysis of association between the mesoregions of the state of Goiás, referring to the prevalence of bovine cysticercosis diagnosed between 2007 and 2014

\begin{tabular}{|c|c|c|c|c|c|c|c|c|}
\hline Mesoregions & Animals slaughtered & Cysticercosis positive & Prevalence (\%) & $95 \% \mathrm{CI}$ & OR & $95 \% \mathrm{CI}$ & $Z$ test & Significance level \\
\hline Norte & 1652806 & 3799 & $0 \cdot 23$ & $0 \cdot 23-0 \cdot 27$ & $1 \cdot 00$ & & & \\
\hline Nordeste & 6687520 & 15652 & $0 \cdot 23$ & $0 \cdot 20-0 \cdot 27$ & $1 \cdot 02$ & $0 \cdot 9828-1 \cdot 0551$ & $1 \cdot 00$ & $0 \cdot 3166$ \\
\hline Leste & 1862932 & 7979 & $0 \cdot 43$ & $0 \cdot 33-0 \cdot 52$ & $1 \cdot 87$ & $1.7962-1.9408$ & $31 \cdot 63$ & $0 \cdot 0000$ \\
\hline Sul & 9098574 & 56269 & $0 \cdot 62$ & $0.57-0.67$ & $2 \cdot 70$ & $2 \cdot 6137-2 \cdot 7915$ & $59 \cdot 20$ & $0 \cdot 0000$ \\
\hline Centro & 3954147 & 40029 & $1 \cdot 01$ & $0 \cdot 91-0 \cdot 111$ & $4 \cdot 44$ & $4 \cdot 2936-4 \cdot 5895$ & $87 \cdot 66$ & $0 \cdot 0000$ \\
\hline Total & 23255979 & 123728 & $0 \cdot 53$ & $0 \cdot 5295-0.5354$ & & & & \\
\hline
\end{tabular}

Mesoregions with OR $>1$ and CI $95 \%>1$ had higher risk for bovine cysticercosis occurrence.

Table 2. Analysis of association between the microregions of the state of Goiás, referring to the prevalence of bovine cysticercosis diagnosed between 2007 and 2014

\begin{tabular}{|c|c|c|c|c|c|c|c|c|}
\hline Microregions & Animals slaughtered & Cysticercosis positive & Prevalence $(\%)$ & $95 \% \mathrm{CI}$ & OR & $95 \% \mathrm{CI}$ & $Z$ test & Significance level \\
\hline São Miguel do Araguaia & 3338585 & 4995 & $0 \cdot 15$ & $0 \cdot 1455-0 \cdot 1538$ & $1 \cdot 00$ & & & \\
\hline Porangatu & 1435146 & 3091 & $0 \cdot 22$ & $0 \cdot 2078-0 \cdot 2230$ & $1 \cdot 44$ & $1 \cdot 3773-1 \cdot 5067$ & $15 \cdot 93$ & $<0 \cdot 0001$ \\
\hline Vão do Paranã & 729676 & 2075 & $0 \cdot 28$ & $0 \cdot 2722-0 \cdot 2966$ & $1 \cdot 90$ & $1 \cdot 8082-2 \cdot 0034$ & $24 \cdot 61$ & $<0 \cdot 0001$ \\
\hline Rio Vermelho & 2514939 & 7474 & $0 \cdot 30$ & $0 \cdot 2905-0 \cdot 3039$ & 1.99 & $1 \cdot 9192-2 \cdot 0619$ & $37 \cdot 59$ & $<0 \cdot 0001$ \\
\hline Chapada dos Veadeiros & 217660 & 708 & $0 \cdot 33$ & $0 \cdot 3014-0 \cdot 3492$ & $2 \cdot 18$ & $2 \cdot 0129-2 \cdot 3566$ & $19 \cdot 35$ & $<0 \cdot 0001$ \\
\hline Quirinópolis & 1976941 & 7429 & $0 \cdot 38$ & $0 \cdot 3673-0 \cdot 3843$ & $2 \cdot 52$ & $2 \cdot 4286-2 \cdot 6094$ & $50 \cdot 39$ & $<0 \cdot 0001$ \\
\hline Aragarças & 833996 & 3183 & $0 \cdot 38$ & $0 \cdot 3684-0 \cdot 3949$ & $2 \cdot 56$ & $2 \cdot 4455-2 \cdot 6733$ & $41 \cdot 33$ & $<0 \cdot 0001$ \\
\hline Catalão & 636586 & 2631 & $0 \cdot 41$ & $0 \cdot 3975-0 \cdot 4291$ & $2 \cdot 77$ & $2 \cdot 6418-2 \cdot 9039$ & $42 \cdot 22$ & $<0 \cdot 0001$ \\
\hline Sudoeste de Goiás & 3404756 & 14153 & $0 \cdot 42$ & $0 \cdot 4088-0 \cdot 4225$ & $2 \cdot 79$ & $2 \cdot 6973-2 \cdot 8772$ & $62 \cdot 18$ & $<0 \cdot 0001$ \\
\hline Entorno do DF & 1133256 & 5904 & $0 \cdot 52$ & $0 \cdot 5077-0 \cdot 5342$ & $3 \cdot 50$ & $3 \cdot 3657-3 \cdot 6296$ & 64.99 & $<0 \cdot 0001$ \\
\hline Ceres & 630048 & 3481 & $0 \cdot 55$ & $0.5342-0.5708$ & $3 \cdot 71$ & $3 \cdot 5504-3 \cdot 8721$ & $59 \cdot 24$ & $<0 \cdot 0001$ \\
\hline Iporá & 558620 & 4051 & $0 \cdot 73$ & $0 \cdot 7029-0 \cdot 7474$ & $4 \cdot 88$ & $4 \cdot 6767-5 \cdot 0819$ & $74 \cdot 75$ & $<0 \cdot 0001$ \\
\hline Anicuns & 1257871 & 9449 & $0 \cdot 75$ & $0 \cdot 7361-0 \cdot 7663$ & $5 \cdot 05$ & $4 \cdot 8807-5 \cdot 2278$ & $92 \cdot 42$ & $<0 \cdot 0001$ \\
\hline Meia Ponte & 1414724 & 11285 & $0 \cdot 80$ & $0 \cdot 7830-0 \cdot 8123$ & $5 \cdot 37$ & $5 \cdot 1903-5 \cdot 5485$ & 98.69 & $<0 \cdot 0001$ \\
\hline Vale do Rio dos Bois & 1226186 & 14897 & $1 \cdot 21$ & $1 \cdot 1955-1 \cdot 2343$ & $8 \cdot 21$ & $7 \cdot 9484-8 \cdot 4757$ & $128 \cdot 48$ & $<0 \cdot 0001$ \\
\hline Pires do Rio & 439381 & 5874 & $1 \cdot 34$ & $1 \cdot 3029-1 \cdot 3708$ & $9 \cdot 04$ & $8 \cdot 7071-9 \cdot 3919$ & $114 \cdot 01$ & $<0 \cdot 0001$ \\
\hline Anápolis & 656021 & 9183 & $1 \cdot 40$ & $1 \cdot 3714-1 \cdot 4282$ & $9 \cdot 47$ & $9 \cdot 1528-9 \cdot 8079$ & $127 \cdot 52$ & $<0 \cdot 0001$ \\
\hline Goiânia & 851587 & 13865 & $1 \cdot 63$ & $1.6013-1 \cdot 6550$ & $11 \cdot 05$ & $10 \cdot 6933-11 \cdot 4099$ & $145 \cdot 16$ & $<0 \cdot 0001$ \\
\hline Total & 23255979 & 123728 & $0 \cdot 53$ & $0 \cdot 5295-0.5354$ & & & & \\
\hline
\end{tabular}

Microregions with OR >1 and CI 95\% >1 had higher risk for bovine cysticercosis occurrence. 

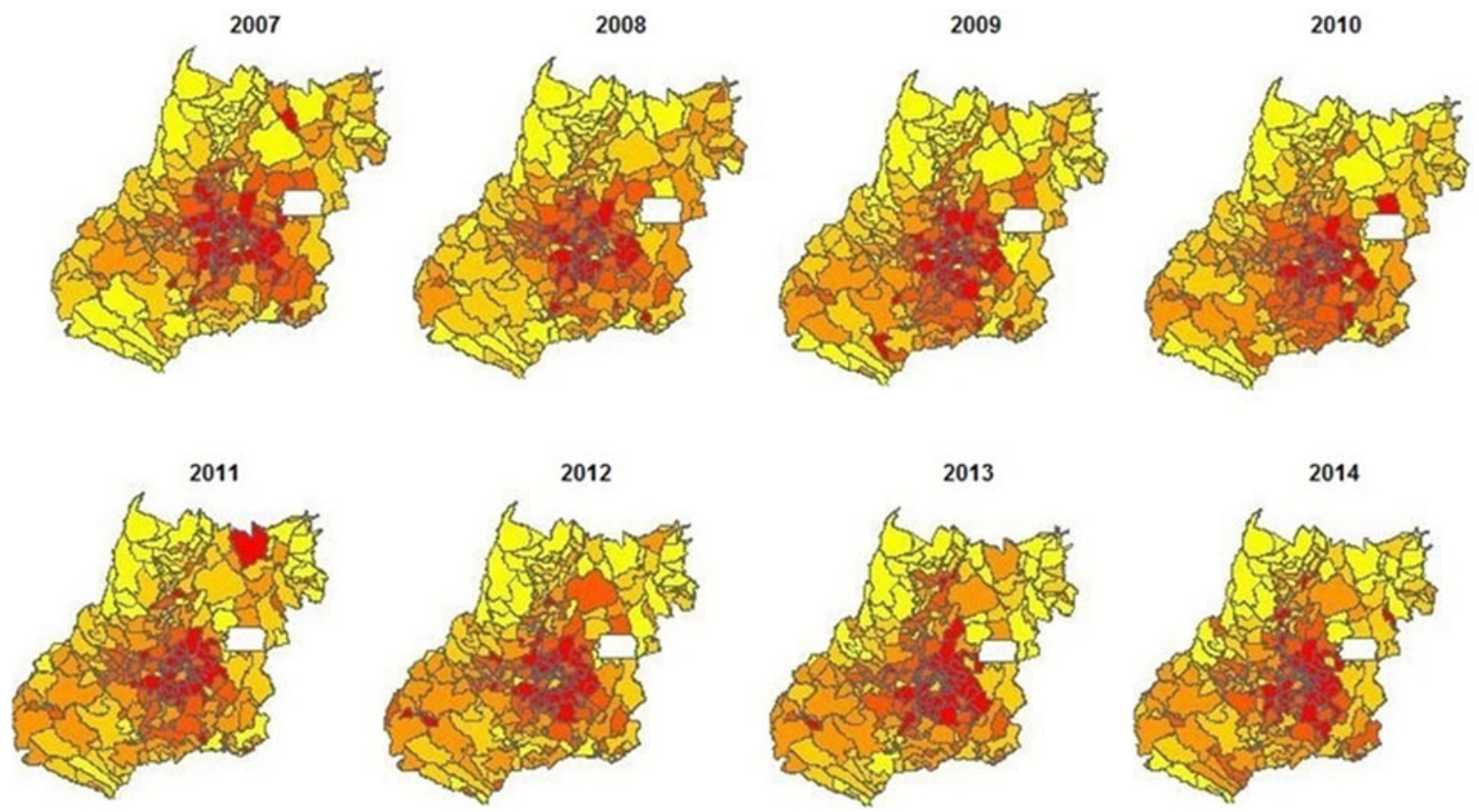

Fig. 3. Spatial distribution of bovine cysticercosis prevalence in municipalities in the state of Goiás, Brazil, through the years 2007-2014.

state of Goiás ranged from US\$9 $260728 \cdot 57$ to US $\$ 11313816 \cdot 67$ due to the presence of unviable and viable cysticercosis, respectively, without considering the economical losses that occur due to beef rendering ( $100 \%$ of discount on paid value).

\section{DISCUSSION}

No significant association $(P>0.05)$ was found in this study between bovine cysticercosis prevalence in municipalities and epidemiological variables, such as human population density per $\mathrm{km}^{2}$, HDI, poverty incidence index, cattle population size, area of temporary tillage (ha), grassland area (ha), sugarcane area (ha), farmer condition (seated without definitive title), numbers of residences without sanitary room and municipalities categorized as touristic. The absence of statistical correlation probably occurred due the low variability of values of bovine cysticercosis prevalence in municipalities located in the state of Goiás (ranged from 0.15 to $0.50 \%$ ) (Table 3 ) or a homogeneity of the other variable values.

The prevalence value assessed in this study $(0.53 \%$; 95\% CI 0.5295-0.5354) was higher than that reported by Santos and Moreira (2010) in the state of Minas Gerais, Brazil (0.37\%). This difference probably occurred due to differences on data obtaining. These authors used viable cysticerci counting to establish prevalence value, while in our study, the prevalence was $0 \cdot 23 \%$ using the same criteria.

This value $(0.53 \%)$ was lower than others obtained in several studies (using the same criteria), as those performed by Dutra et al. (2012); Silva et al. (2012) and Rossi et al. (2015). These authors established values of bovine cysticercosis prevalence of 0.78 , 3.23 and $0.71 \%$, respectively. It is important to emphasize that these results refers to data obtained in the same state, but these differences are difficult to explain due to differences on the criteria used in other studies, such as sample size and the period.

The prevalence value assessed in this study $(0.53 \%)$ is lower than the value reported in Brazil (1.05\%) (Dutra et al. 2012), and in the states of Paraná (2.2\%) (Guimarães-Peixoto et al. 2012) and São Paulo (4.8\%) (Ferreira et al. 2014). In the other hand, the prevalence is similar to the value reported in the state of Mato Grosso $(0.08 \%)$ (Rossi et al. 2016), which is located in the same Brazilian region (West-Centre). A possible explanation for this difference of bovine cysticercosis prevalence among the states of Paraná/São Paulo and Mato Grosso/Goiás is the differences on human population density (pop. per $\mathrm{km}^{2}$ ). The values in the states of Paraná and São Paulo are $52 \cdot 4$ and $166 \cdot 2$, while it is $3 \cdot 3$ and $17 \cdot 6$ in Mato Grosso and Goiás, respectively. The differences on population size of definitive and intermediate hosts influence $T$. saginata life cycle and bovine cysticercosis prevalence (Rossi et al. 2016).

A similarity can be observed comparing the prevalence assessed in this study with those reported in other countries, such as Iran $(0 \cdot 25 \%)$ (Khaniki et al. 2010), Chile (0.58\%) (Faustina et al. 2012) and European countries (<1\%) (Laranjo-González et al. 2016). 
The no-detection of bovine cysticercosis in animals slaughtered from two municipalities does not mean a real absence of this disease at these areas due to the low sensitivity of the ongoing model of meat inspection and the practice of slaughter without inspection (illegal), which remains occurring in this state (Lopes et al. 2011).

Another important result is the similarity observed in the municipalities in the state of Goiás regarding the prevalence of animals infected with viable and unviable cysticercosis. There is an ideology that the risk for $T$. saginata-cysticercosis occurrence need to be assessed using data of viable cysticerci detection due to animal's movement in several farms during their raising, not allowing to establish in which farm the infection occurred. However, it is important to mention that the areas with higher prevalence of viable and unviable cysticercosis were very similar for evaluation in municipalities (Figs. 2A and B).

Ferreira et al. (2014) stated that bovine cysticercosis is not only related to bovine population size but also is closely related to the presence of human beings. The comparison among bovine cysticercosis prevalence (viable and unviable) with cattle distribution in this state is shown in Figs. 4A and B. Besides that, in this study, similarity or tendency between prevalence of bovine cysticercosis and high human population is observed in their spatial distribution as shown in Figs. 4A and C.

Besides the low value of bovine cysticercosis prevalence in the state of Goiás compared with other Brazilian states, this disease causes important economical losses for beef farms and cattle slaughterhouses. Thus, sanitary programmes aiming its control need to be adopted in Brazil. These programmes need to include prophylactic measures useful to control the risk factors reported in Brazil, such as the access to contaminated water or raising of animals in high-populated areas (Ferreira et al. 2014; Rossi et al. 2015; Rossi et al. 2016).

The economical losses due to bovine cysticercosis occurrence in this Brazilian state through 8 years ranged from US $\$ 9260728.57$ to US $\$ 11313816 \cdot 67$ without considering the economical losses due to rendering of infected carcasses. Furthermore, according to the data published in Annual Report 2015, the Brazilian beef production chain in Brazil generated $\mathrm{R} \$ 380$ billion during 2013 and sale of cattle to slaughter generated $\mathrm{R} \$ 62.7$ billion (BRAZIL, 2014). Comparing these values with the economical losses during 2013 ( $\mathrm{R} \$ 12$ million) due to the occurrence of only one disease (bovine cysticercosis) in one low-prevalent Brazilian state (Goiás), allow us to infer that the economical losses are really important for Brazilian beef production chain considering the high prevalence of this disease in other Brazilian states. 
(a)

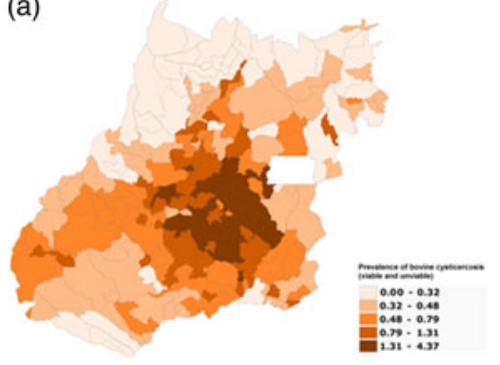

(b)

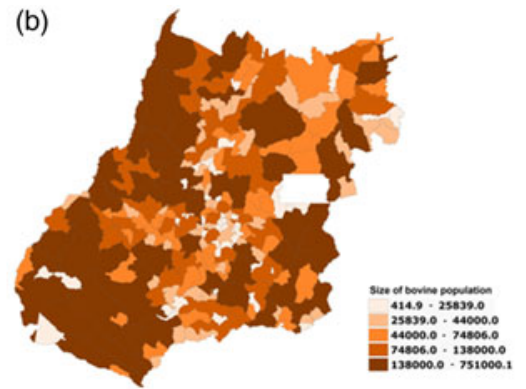

(c)

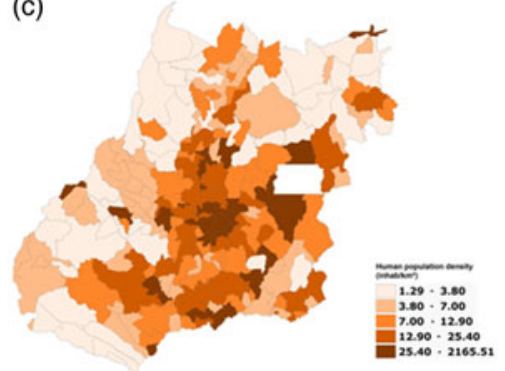

Fig. 4. Spatial distribution of bovine cysticercosis prevalence (a), cattle population size (b) and human population density (c) in municipalities in the state of Goiás, Brazil, through the years 2007-2014.

\section{Concluding remarks}

Bovine cysticercosis prevalence in the state of Goiás, Brazil, was $0.53 \%(95 \%$ CI $0.5295-0.5354)$ from 2007 to 2014. The mesoregions (Central and South) and the microregions Goiânia, Anápolis, Pires do Rio and Vale do Rio dos Bois showed a higher risk for bovine cysticercosis detection. The economical losses ranged from US\$9 $260728 \cdot 57$ to 11313816.67 due to occurrence of unviable and viable cysticercosis, respectively. These results highlight the importance of meat inspection to improve the knowledge about high-occurrence areas that requires interventions in order to reduce the economical losses for beef production chain.

\section{FINANCIAL SUPPORT}

This research received no specific grant from any funding agency, commercial or not-for-profit sectors.

\section{REFERENCES}

Brazil, Ministry of Agriculture, Livestock and Food Supply. (2014). Data of cattle herds in Brazil - 2014. Available in: http://www.agricultura.gov.br/arq_editor/file/Dados $\% 20 \mathrm{de} \% 20$ rebanho $\% 20$ bovino $\% 20 \mathrm{e} \%$ 20bubalino\%20do\%20Brasil\%202014.pdf, Accessed 29 march 2016. CEPEA. Centro de Estudos Avançados em Economia Aplicada - ESALQ/ USP. Disponível em. http://www.cepea.esalq.usp.br. Accessed 29 march 2016. Dutra, L. H., Girotto, A., Vieira, R. F. C., Vieira, T. S. W. J., Zangirolamo, A. F., Marquês, F. A. C., Headley, S. A., Vidotto, O. (2012). The prevalence and spatial epidemiology of cysticercosis in slaughtered cattle from Brazil. Ciências Agrárias 33, 1887-1896.

Faustina, C., Gaston, V., Enrique, P., Veronica, R., Willy, M. L., Carmen, G. (2012). Prevalence of Cysticercus bovis by gender, category and level of infection in cattle slaughtered in southern Chile. Selva Andina Research Society 3(2), 4-13.

Ferreira, M. M., Revoredo, T. B., Ragazzi, J. P., Soares, V. E., Ferraldo, A. S., Mendonça, R. P., Lopes, W. D. Z. (2014). Prevalência, distribuição espacial e fatores de risco para cisticercose bovina no estado de São paulo. Pesquisa Veterinária Brasileira 34 (12), 1181-1185.

Fukuda, R. T. (2003). Contribuição ao Estudo da Epidemiologia da Cisticercose Bovina na Região Administrativa de Barretos. Aspectos ambientais e econômicos. Tese de doutorado. Universidade Estadual Paulista, Faculdade de Ciências Agrárias e Veterinárias, Jaboticabal, Brasil, 127 p. Giovannini, C. I., Carvalho, T. S., Cabral, J. F., Brasil, R. B., Santos, P. A. (2014). Aspectos econômicos e epidemiológicos da cisticercose bovina Revisão de Literatura. Rev. Eletron. UNIVAR 12 (2), 6-12.
Guimarães-Peixoto, R. P. M., Souza, V. K., Pinto, P. S. A., Santos, T. O. (2012). Distribuição e identificação das regiões de risco para a cisticercose bovina no estado do Paraná. Pesquisa Veterinária Brasileira 32, 975979.

IBGE - Instituto Brasileiro de Geografia e Estatística. (2016). Disponível em. http://cidades.ibge.gov.br/xtras/uf.php? lang $=\&$ coduf $=52 \&$ search $=$ goias

Khaniki, G. R., Raei, M., Kia, E. B., Haghi, A. M., Selseleh, M. (2010). Prevalence of bovine cysticercosis in slaughtered cattle in Iran. Tropical Animal Health 42, 141-143.

Laranjo-González, M., Devleesschauwer, B., Gabriel, S., Dorny, P., Allepuz, A. (2016). Epidemiology, impact and control of bovine cysticercosis in Europe: a systematic review. Parasites Vectors 9, 1-12.

Lopes, W. D. Z., Santos, T. R., Soares, V. E., Nunes, J. L. N., Mendonça, R. P., Lima, R. C. A., Sakamoto, C. A. M., Costa, G. H. N., Thomaz-Soccol, V. T., Oliveira, G. P., Costa, A. J. (2011). Preferential infection sites of Cysticercus bovis in cattle experimentally infected with Taenia saginata eggs. Research in Veterinary Science $\mathbf{9 0}$, 84-88.

Lopes, W. D. Z., Cruz, B. C., Soares, V. E., Nunes, J. L. N., Teixeira, W. F., Maciel, W., Buzulini, C., Pereira, J. C., Felippelli, G., Thomaz-Soccol, V. T., Oliveira, G. P., Costa, A. J. (2014). Historic of therapeutic efficacy of albendazol sulphoxide administered in different routes, dosages and treatment schemes, against Taenia saginata Cysticercus in cattle experimentally infected. Experimental Parasitology 137, 14-20.

Minozzo, J. C., Gusso, R. L. F., Castro, E. A., Lago, O., Soccol, V. T. (2002). Experimental bovine infection with Taenia saginata eggs: recovery rates and cysticerci location. Arquivos de Biologia e Tecnologia 4, $451-455$.

Onyango-Abuje, J. A., Hughes, G., Opicha, M., Nginyi, M. K., Wright, H. S., Harrison, S. J. L. (1996). Diagnosis of Taenia saginata cysticercosis in Kenyan cattle by antibody and antigen ELISA. Parasitology Veterinary 61, 221-230.

Projeções do Agronegócio - Brasil 2013/14 a 2023/24. Ministério da Agricultura Pecuária e Abastecimento - MAPA. Disponível em. http://www.agricultura.gov.br/arq_editor/file/projecoes_2013-2014_20232024.pdf. Accessed 29 march 2016.

Rossi, G. A. M., Hoppe, E. G. L., Mathias, L. A., Martins, A. M. C. V., Mussi, L. A., Prata, L. F. (2015). Bovine cysticercosis in slaughtered cattle as na indicator of Good Agricultural Practices (GAP) and epidemiological risk factors. Preventive Veterinary Medicine 118(4), 504-508.

Rossi, G. A. M., Simoni, H. A. S., Lopes, W. D. Z., Almeida, H. M. S., Soares, V. E., Vidal, A. M. C., Ferraudo, A. S., Mathias, L. A. (2016). Prevalence and geospatial distribution of bovine cysticercosis in the state of Mato Grosso, Brasil. Preventive Veterinary Medicine 130, 94-98.

Santos, C. C. G., Moreira, M. D. (2010). Ocorrência da cisticercose bovina em matadouro frigorífico exportador de Ituiutaba/MG. http:// www.fazu.br/ojs/index.php/posfazu/article/viewFile/325/231.

Silva, S. M., Rocha, R. N., Oliveira, S. L., Netto, A. P. C. (2012). Prevalência de cisticercose bovina no estado de Goiás. Revista Agrarian 5(16), 187-192.

Thrusfield, M. V. (2010). Veterinary Epidemiology, 3rd Edn. WileyBlackwell, Rocca, São Paulo, 556p. 